\title{
Zinc-based Degradable Biomaterials - Limitations and Enhancements
}

Tomáš Lovaši, Jan Pinc, Ilona Voňavková

Department of Metals and Corrosion Engineering, University of Chemistry and Technology Prague. Technická 5, 16628 Praha 6 - Dejvice. Czech Republic. E-mail: Tomas.Lovasi@vscht.cz, Jan.Pinc@vscht.cz, Ilona.Vonavkova@vscht.cz

Nowadays there is a high trend and effort to find a suitable biodegradable metal, whose mechanical properties would be the same or higher to those of currently used biomaterials. Current biomaterials, such as stainless steels, cobalt-chromium alloys, and titanium alloys have superior mechanical properties, machinability, and durability, but are considered nondegradable, and long-term clinical complications may occur. Their biggest disadvantage is that the patient must have undergone a second removal surgery. Therefore, new biodegradable materials have been developed to eliminate the shortcomings of current biomaterials. Magnesium (Mg), iron (Fe) and zinc ( $\mathrm{Zn}$ ) based alloys have been proposed as biodegradable metals for medical application. Iron-based alloys show good mechanical properties compared to magnesium-based alloys. However, both of them exhibit bad corrosion properties, because the degradation rate of magnesium has proven to be high. On the other hand, the degradation of iron-based alloys is too slow in a physiological environment. The corrosion attack of both materials is not typically uniform. Therefore, zinc is proven to be a promising material for this application.

Keywords: Mechanical properties, corrosion properties, biomaterials, biodegradable metals

\section{Introduction}

Nowadays, there are large range of biomaterials, which are most often used for hard tissue reconstruction and replacement. The most commonly used are titanium and its alloys, stainless steels as well as cobalt-chromium alloys [1]. All these materials are characterized by excellent properties, which include mainly mechanical properties, machinability, and formability, but also economically, their affordability [2]. The usability of those materials is optimal in the cases, where the organism is not possible to regenerate destroyed tissue (age, illness) alone. On the contrary, those materials are not suitable for using them for the children and must be often re-operated in order to prevent the destruction of growing bone. To eliminate such problems, new materials called biodegradable biomaterials have been developed (we can also meet the synonymic concept bioabsorbable metals) [3]. It is a revolutionary biomaterial that is gradually degrading, while still providing the necessary support for complete healing. Thus, in such a case, the patient avoids the sur- gery that would be necessary for a conventional biomaterial [3, 4]. Graphical processing of the theoretical functionality of biodegradable material is shown in Fig 1. The concept of biodegradable materials is simple. The implanted material should provide support until the tissue gradually regenerates [5]. Another very important condition for the biodegradable material is its corrosion resistance. As can be seen in Fig. 1, the degradation of the biodegradable implant should be as fast that the mechanical properties do not reach a value of whole system failure [5]. More precisely, the corrosion rate should be as fast as new bone growth. Corrosion resistance is also associated with the fact that not only the material but also its corrosion products should be non-toxic and biocompatible [6]. Until this moment, only the conditions connected with the corrosion process were mentioned. It is obvious that the corrosion process is in the case of biodegradable metals crucial and affects mechanical properties as well as the behavior in the organism. Magnesium, iron, and zinc belong to biodegradable metals group due to fulfilling the basic requirements mentioned above [7].

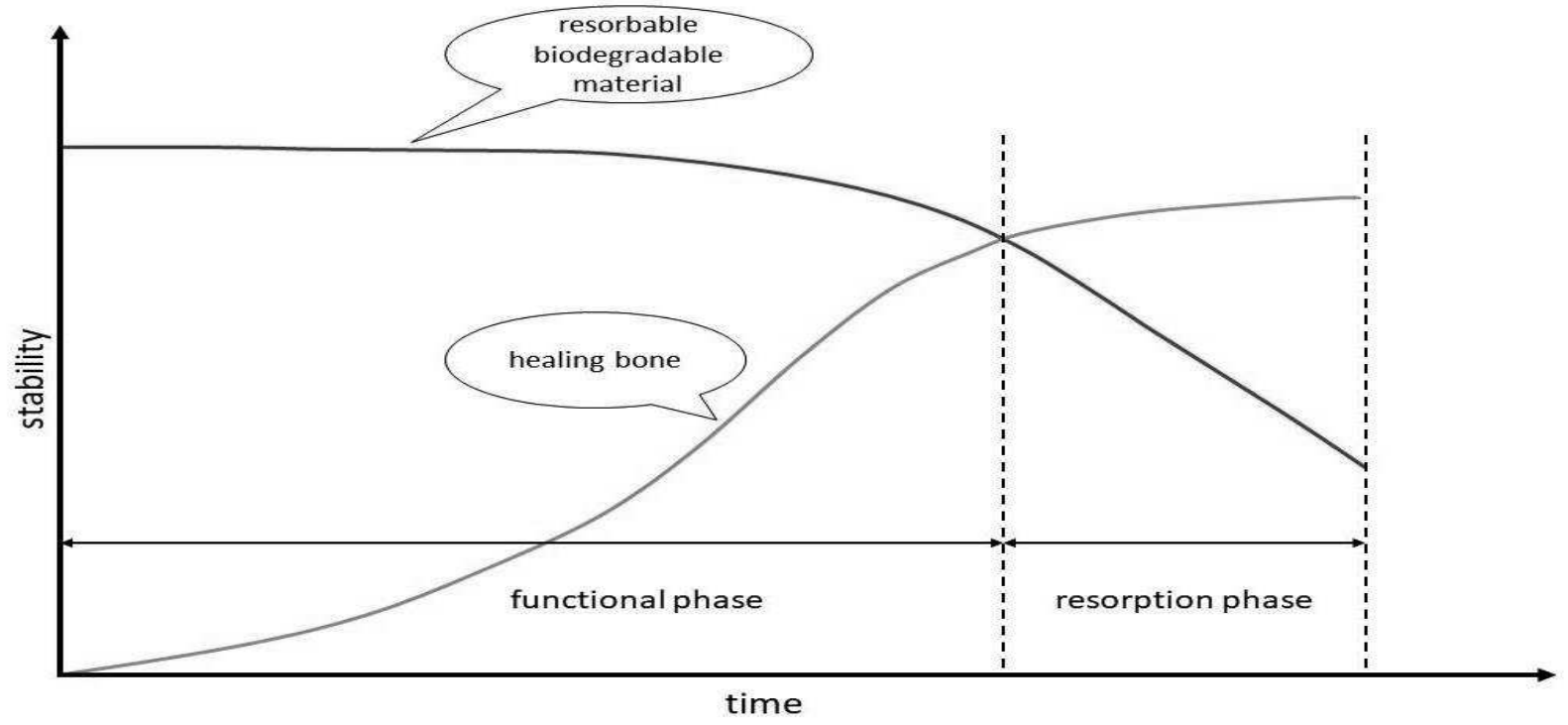

Fig. 1 The theoretical principle of biodegradable material 


\section{Magnesium}

Magnesium has been studied for decades as a biodegradable material [8-12]. One of the first clinical applications of pure magnesium implant was done by Lambotte in 1906 [11]. The results of magnesium research were at this early stage unsatisfactory and pure magnesium platelets were removed due to extensive gas cavities, local swelling and severe pain [12]. According to those observations was found that the corrosion process of magnesium and its alloys is accompanied by the evolution of hydrogen gas and the amount depends on the corrosion rate [10]. The production of high amounts of gas in a short period of time is not desirable for clinical application and may cause significant problems accompanied by the heart or brain damage. The knowledge of the corrosion process is quite important, and it is described by Eq. (1-3).

$$
\begin{aligned}
& \text { Anodic reaction } \quad \mathrm{Mg} \rightarrow \mathrm{Mg}^{2+}+2 \mathrm{e}^{-} \\
& \text {Cathodic reaction } \quad 2 \mathrm{H}_{2} \mathrm{O}+2 \mathrm{e}^{-} \rightarrow \mathrm{H}_{2}+2 \mathrm{OH}^{-} \\
& \text {Overall } \quad \mathrm{Mg}^{2+}+2 \mathrm{OH}^{-} \rightarrow \mathrm{Mg}(\mathrm{OH})_{2}
\end{aligned}
$$

During the corrosion processes, hydrogen gas and also $\mathrm{Mg}^{2+}$ are released. Magnesium is commonly contained in the human body and therefore the release of $\mathrm{Mg}^{2+}$ is not harmful. The recommended dietary allowances of magnesium is for male in the range $240-420^{*} \mathrm{mg} /$ day and for female in the range $240-320 * \mathrm{mg} /$ day (*dependent of age) $[3,13]$. If this concentration is exceeded, health complications may occur (for example hypermagnesemia) [14].

\section{Iron}

Another candidate for a biodegradable biomaterial is iron and its alloys [15]. Iron has better mechanical properties and a slower rate of degradation (in cardiovascular applications).

Although iron is contained in the human body to the greatest extent, an overdose of iron may not always be favorable. Iron degrades according to the following Eq. (4-7):

$$
\begin{aligned}
& \text { Anodic reaction } \quad \mathrm{Fe} \rightarrow \mathrm{Fe}^{2+}+2 \mathrm{e}^{-} \\
& \text {Cathodic reaction } \mathrm{H}_{2} \mathrm{O}+1 / 2 \mathrm{O}_{2}+2 \mathrm{e}^{-} \rightarrow 2 \mathrm{OH}^{-} \\
& \text {Overall } \mathrm{Fe}^{2+}+2 \mathrm{OH}^{-} \rightarrow \mathrm{Fe}(\mathrm{OH})_{2} \\
& 4 \mathrm{Fe}(\mathrm{OH})_{2}+\mathrm{O}_{2}+\mathrm{H}_{2} \mathrm{O} \rightarrow 4 \mathrm{Fe}(\mathrm{OH})_{3}
\end{aligned}
$$

The resulting $\mathrm{Fe}^{2+}$ ions may not form the $\mathrm{Fe}(\mathrm{OH})_{\mathrm{X}}$ $(\mathrm{X}=2$ or 3 ) and they may accumulate in the cells resulting in toxicity [16]. The literature indicates that the safe concentration of iron, i.e. the recommended dietary allowances, should be approximately $10 \mathrm{mg} /$ day $[3,17]$. Therefore, it is necessary for this material to achieve a slower release of $\mathrm{Fe}^{2+}$, resulting in reduction of its concentration and therefore is no longer harmful to the human body. As a consequence, it is impossible to reach the optimal ratio between the corrosion rate and the number of released ions. Another disadvantage, when used in the human body, is that the corrosion products are retained in the tissues for a long time.

\section{Zinc}

Last but not least, the zinc is also considered as a biodegradable metal [18]. The main advantage is almost ideal corrosion behavior of zinc under the physiological conditions compared to those of pure magnesium and iron. The corrosion rate lies between mentioned metals and the corrosion process is not connected with direct hydrogen evolution [6], as shown in the equation 9.

$\begin{array}{ll}\text { Anodic reaction } & \mathrm{Zn} \rightarrow \mathrm{Zn}^{2+}+2 \mathrm{e}^{-} \\ \text {Cathodic reaction } & 2 \mathrm{H}_{2} \mathrm{O}+\mathrm{O}_{2}+4 \mathrm{e}^{-} \rightarrow 4 \mathrm{OH}^{-} \\ \text {Overall } \quad \mathrm{Zn}^{2+}+2 \mathrm{OH}^{-} \rightarrow \mathrm{Zn}(\mathrm{OH})_{2}\end{array}$

In addition, the corrosion products are completely bioresorbable, which is a crucial parameter for such materials [6]. For these reasons, the following text will refer exclusively to zinc. The zinc is an essential element participating in various biological functions as brain activity or mineralization of bones and is localized especially in the bones and muscles [19, 20]. Such information supports the biodegradable zinc idea and its usability in the bone healing process. The value of recommended daily allowance is ranged between $8-18 \mathrm{mg} /$ day and the excess of the metal can cause problems with the copper deficiency $[3,21,22]$.

Limitations of zinc are connected with the mechanical properties and lower value of recommended daily allowance [23]. It can be seen from Tab. 1, that the mechanical properties of pure zinc are worse compared with metal used for the implants preparation. The problem is often solved by adding elements or compounds into pure zinc and by a suitable manner of processing. The added components are often those which normally occur in the human body as essential elements (e.g. Mg, Ca, Sr) [24-26] or compounds (e.g. hydroxyapatite, collagen) [27, 28]. Another advantage of adding those components is the possibility of corrosion rate setting, according to conditions that are needed. The setting is connected especially with the exposed surface of the metal (Fig. 2b) and galvanic cells formation (Fig. 2d). More precisely, the adding of the components leads to decreasing of the specific surface thus decreasing of corrosion rate as well. On the contrary, the formation of the galvanic cell leads to an increase in the corrosion rate. Those statements are general and can be affected by many parameters (e.g. porosity) (Fig. 2a, b).

According to this, it is clear that the manner of material processing plays a significant role in the resulting properties. The zinc-based materials, which were prepared by plasma spraying [33], spark plasma sintering, casting and extrusion processes, are shown in Fig. 2. The differences in the structures are visible for the first sight but the crucial parameter is the grain size, in the connection with the mechanical properties. The recrystallization temperature of pure zinc is quite low and the grain size can change in wide ranges according to the conditions of preparation [34]. Together with the poor mechanical performance, it is important to mention some approaches and the grain sizes of resulting structures (Tab 2). 
Tab. 1 Mechanical properties of individual biodegradable materials [10, 15, 16, 29-32]

\begin{tabular}{|l|c|c|c|c|}
\hline Materials & Young's modulus [GPa] & Ultimate tensile strength [MPa] & Elongation [\%] & Hardness \\
\hline Stainless steel & $189-205$ & $490-695$ & $40-52$ & $320-350 \mathrm{HB}$ \\
\hline Pure Fe & $200-205$ & $210-245$ & $40-50$ & $80 \mathrm{HB}$ \\
\hline Pure $\mathrm{Zn}$ & 108 & 88 & 6 & $39 \mathrm{HV}$ \\
\hline Pure $\mathrm{Mg}$ & $44-45$ & 160 & 3 & $30 \mathrm{HB}$ \\
\hline Magnesium alloy & $41-45$ & $65-258$ & $2-13$ & $57-69 \mathrm{HV}$ \\
\hline Cortical bone & $3-30$ & $130-180$ & - & - \\
\hline Cancellous bone & $0.01-1.57$ & $1.5-38$ & - & - \\
\hline
\end{tabular}

Tab. 2 The grain sizes of zinc prepared by defferent approaches

\begin{tabular}{|l|l|}
\hline Manner of processing & Grain size $[\mu \mathrm{m}]$ \\
\hline Plasma spraying & $1-50$ \\
\hline Spark plasma sintering & $1-30$ \\
\hline Extrusion & $5-20$ \\
\hline
\end{tabular}

Last but not least, the porosity belongs to the group of significant conditions for the bone implants. It is obvious, that the porosity of biodegradable materials affects the
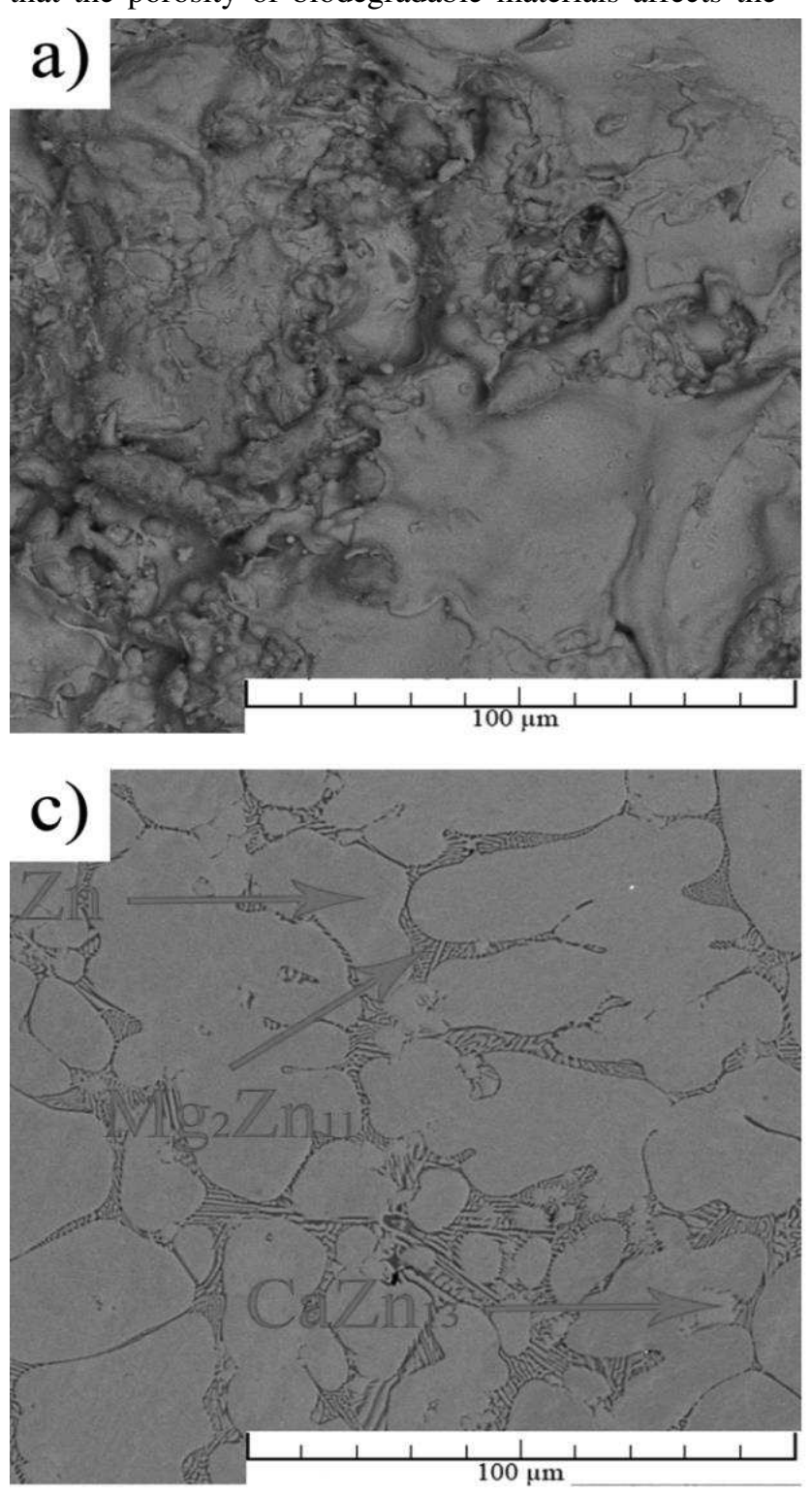

Fig. 2 SEM images of zinc-based materials prepared by a) plasma spraying b) spark plasma sintering c) casting d) extrusion

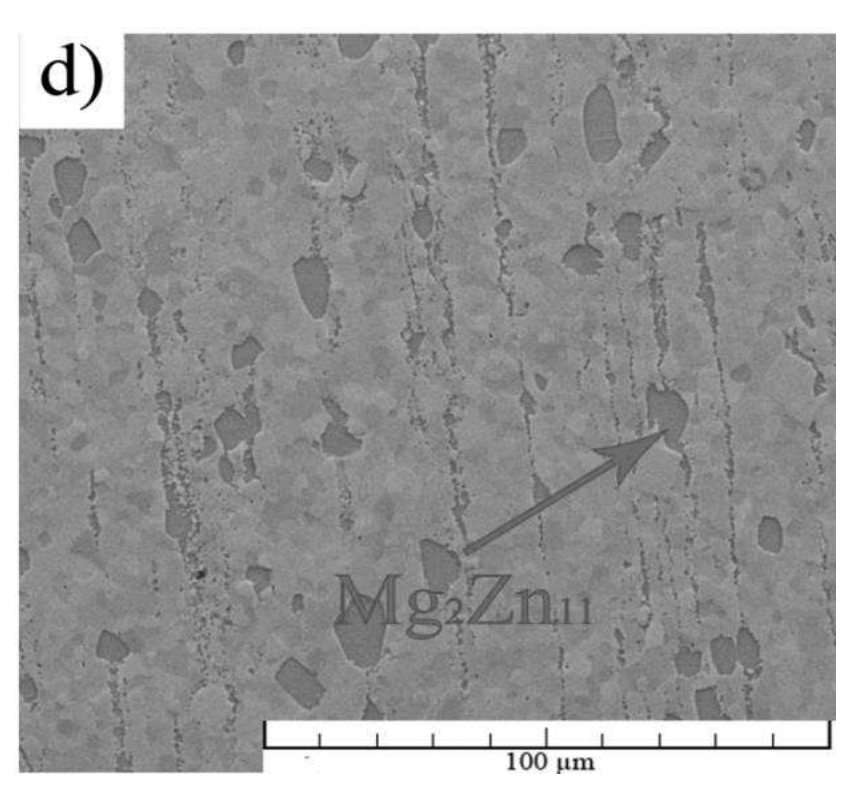

corrosion properties due to the increase of the surface. This fact can be a little bit problematic in case of biodegradable zinc materials. The reason is that the higher porosity can increase the corrosion rate above the ideal value. Secondly, this increase can lead to premature failure due to the presence of defects and changes in dimensions caused by the corrosion process. The information suggests that the zinc-based biodegradable materials should be non-porous, until the problem with the mechanical properties will be solved.
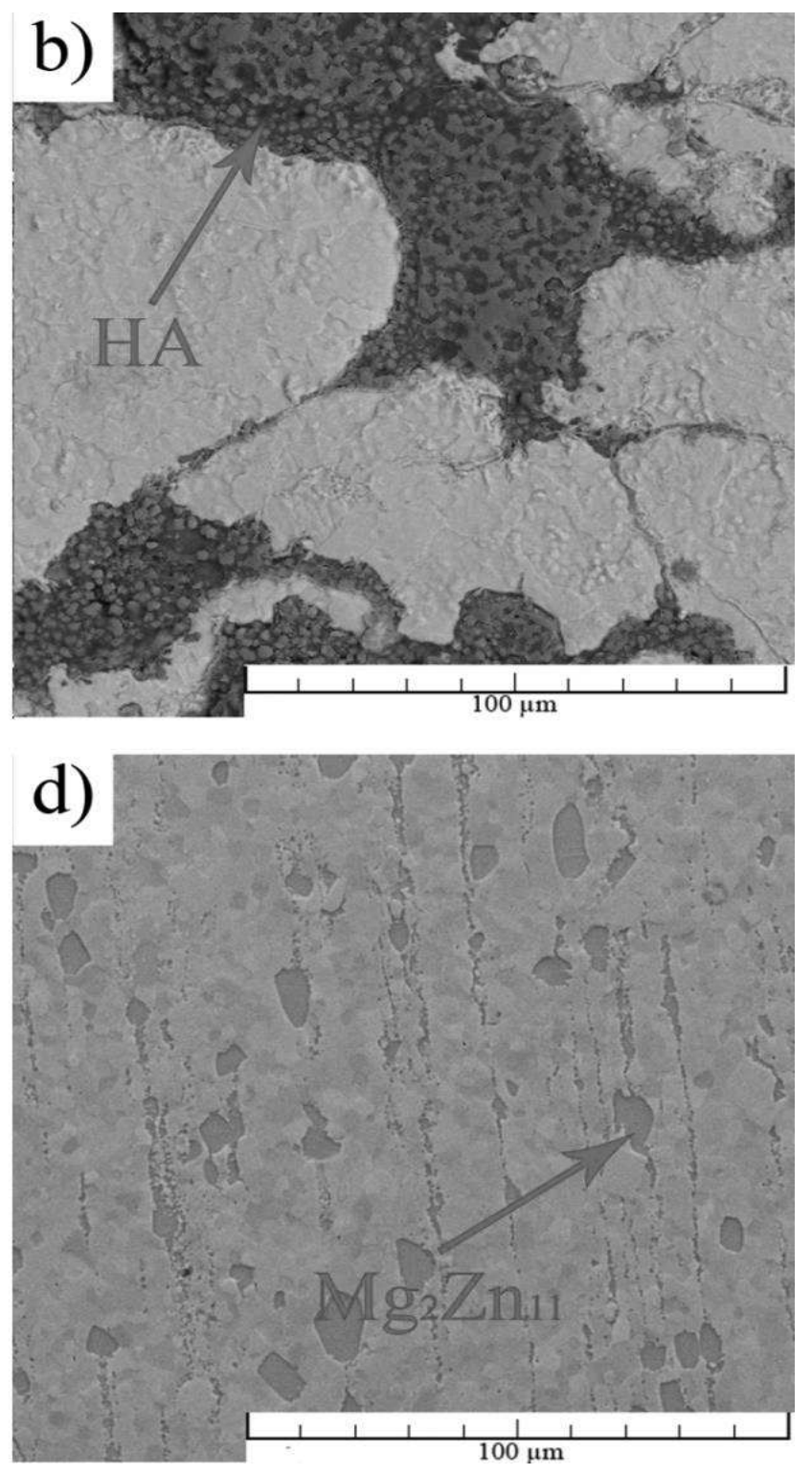


\section{Conclusion}

In this brief overview of all metals, which are studied as a potentially biodegradable were discussed predominantly from the view of corrosion. Special attention was paid to zinc-based materials. Those materials are the newest from the mentioned metals ( $\mathrm{Mg}, \mathrm{Fe}, \mathrm{Zn})$ and show potential as a material for the biodegradable implant preparation. Despite the disadvantages of zinc connected especially with the mechanical properties, the corrosion properties are almost ideal. The corrosion properties are the most important which is obvious from the intended application. Due to that, the zinc seems to be the ideal material for such application, and it is necessary to solve the problems related to structure in order to use those materials in the human body without negative reactions.

\section{Acknowledgment}

The authors would like to thank the Czech Science Foundation (project no. 18-06110S) and specific university research (MSMT no. 21-SVV/2019) for financial support.

\section{References}

[1] MOSTAED, E., SIKORA-JASINSKA, M., DRELICH, J.W. and VEDANI, M. (2018), Zincbased alloys for degradable vascular stent applications. In: Acta Biomaterialia, Vol. 71. pp. $1-23$.

[2] SU, Y., COCKERILL, I., WANG, Y., QIN, Y.-X., CHANG, L., ZHENG, Y. and ZHU, D. (2019), Zinc-Based Biomaterials for Regeneration and Therapy. In: Trends in Biotechnology, Vol. 37, No. 4, pp. 428-441.

[3] ZHENG, Y.F., GU, X.N. and WITTE, F. (2014), Biodegradable metals. In: Materials Science and Engineering: R: Reports, Vol. 77. pp. 1-34.

[4] CHEN, Q. and THOUAS, G.A. (2015), Metallic implant biomaterials. In: Materials Science and Engineering: R: Reports, Vol. 87. pp. 1-57.

[5] HERMAWAN, H., DUBE, D. and MANTOVANI, D. (2010), Developments in metallic biodegradable stents. In: Acta Biomater, Vol. 6, No. 5, pp. 1693-7.

[6] BOWEN, P.K., DRELICH, J. and GOLDMAN, J. (2013), Zinc exhibits ideal physiological corrosion behavior for bioabsorbable stents. In: Adv Mater, Vol. 25, No. 18, pp. 2577-82.

[7] PARAMITHA, D., ULUM, M.F., PURNAMA, A., WICAKSONO, D.H.B., NOVIANA, D. and HERMAWAN, H. (2017). 2 - Monitoring degradation products and metal ions in vivo. In: Monitoring and Evaluation of Biomaterials and their Performance In Vivo, pp. 19-44. Woodhead Publishing,

[8] DVORSKÝ, D., KUBÁSEK, J., KRISTIANOVÁ, E. and VOJTĚCH, D. (2018),
Corrosion resistant magnesium-based composite material with $\mathrm{MgF} 2$ continuous network prepared by powder metallurgy. In: Manufacturing Technology, Vol. 18, No. 5, pp. 737-741.

[9] DVORSKY, D., KUBASEK, J. and VOJTECH, D. (2017), Corrosion protection of WE43 magnesium alloy by fluoride conversion coating. In: Manufacturing Technology, Vol. 17, No. 4, pp. 440-446.

[10] LUTHRINGER, B.J., FEYERABEND, F. and WILLUMEIT-ROMER, R. (2014), Magnesiumbased implants: a mini-review. In: Magnes Res, Vol. 27, No. 4, pp. 142-54.

[11] WAIZY, H., SEITZ, J.-M., REIFENRATH, J., WEIZBAUER, A., BACH, F.-W., MEYERLINDENBERG, A., DENKENA, B. and WINDHAGEN, H. (2012), Biodegradable magnesium implants for orthopedic applications. In: Journal of Materials Science, Vol. 48, No. 1, pp. 39-50.

[12] WITTE, F. (2010), The history of biodegradable magnesium implants: A review. In: Acta Biomaterialia, Vol. 6, No. 5, pp. 1680-1692.

[13] INSTITUE OF MEDICINE. (1997). Magnesium. In: Dietary Reference Intakes for Calcium, Phosphorus, Magnesium, Vitamin D, and Fluoride, pp. 190-250. Washington (DC).

[14] AL ALAWI, A.M., MAJONI, S.W. and FALHAMMAR, H. (2018), Magnesium and Human Health: Perspectives and Research Directions. In: Int J Endocrinol, Vol. 2018, No. pp. 9041694.

[15] FRANCIS, A., YANG, Y., VIRTANEN, S. and BOCCACCINI, A.R. (2015), Iron and iron-based alloys for temporary cardiovascular applications. In: Journal of Materials Science: Materials in Medicine, Vol. 26, No. 3, pp. 138.

[16] ZHANG, E., CHEN, H. and SHEN, F. (2010), Biocorrosion properties and blood and cell compatibility of pure iron as a biodegradable biomaterial. In: Journal of Materials Science: Materials in Medicine, Vol. 21, No. 7, pp. 21512163.

[17] INSTITUE OF MEDICINE. (2001). Iron. In: Dietary Reference Intakes for Vitamin A, Vitamin K, Arsenic, Boron, Chromium, Copper, Iodine, Iron, Manganese, Molybdenum, Nickel, Silicon, Vanadium, and Zinc, pp. 290-393. The National Academies Press, Washington (DC).

[18] MOSTAED, E., SIKORA-JASINSKA, M., MOSTAED, A., LOFFREDO, S., DEMIR, A.G., PREVITALI, B., MANTOVANI, D., BEANLAND, R. and VEDANI, M. (2016), Novel Zn-based alloys for biodegradable stent applications: Design, development and in vitro 
degradation. In: J Mech Behav Biomed Mater, Vol. 60. pp. 581-602.

[19] KATARIVAS LEVY, G., GOLDMAN, J. and AGHION, E. (2017), The Prospects of Zinc as a Structural Material for Biodegradable ImplantsA Review Paper. In: Metals, Vol. 7, No. 10, pp.

[20] MILLS, C.F. (2013). Zinc in Human Biology. In: pp. Springer London, London.

[21] WANG, C., YANG, H.T., LI, X. and ZHENG, Y.F. (2016), In Vitro Evaluation of the Feasibility of Commercial Zn Alloys as Biodegradable Metals. In: Journal of Materials Science \& Technology, Vol. 32, No. 9, pp. 909-918.

[22] WILLIS, M.S., MONAGHAN, S.A., MILLER, M.L., MCKENNA, R.W., PERKINS, W.D., LEVINSON, B.S., BHUSHAN, V. and KROFT, S.H. (2005), Zinc-induced copper deficiency: a report of three cases initially recognized on bone marrow examination. In: Am J Clin Pathol, Vol. 123, No. 1, pp. 125-31.

[23] INSTITUE OF MEDICINE. (2001). Zinc. In: Dietary Reference Intakes for Vitamin A, Vitamin K, Arsenic, Boron, Chromium, Copper, Iodine, Iron, Manganese, Molybdenum, Nickel, Silicon, Vanadium, and Zinc, pp. 442-501. The National Academies Press, Washington, DC.

[24] GONG, H., WANG, K., STRICH, R. and ZHOU, J.G. (2015), In vitro biodegradation behavior, mechanical properties, and cytotoxicity of biodegradable $\mathrm{Zn}-\mathrm{Mg}$ alloy. In: J Biomed Mater Res B Appl Biomater, Vol. 103, No. 8, pp. 163240 .

[25] LI, H.F., XIE, X.H., ZHENG, Y.F., CONG, Y., ZHOU, F.Y., QIU, K.J., WANG, X., CHEN, S.H., HUANG, L., TIAN, L. and QIN, L. (2015), Development of biodegradable $\mathrm{Zn}-1 \mathrm{X}$ binary alloys with nutrient alloying elements $\mathrm{Mg}, \mathrm{Ca}$ and Sr. In: Sci Rep, Vol. 5. pp. 10719.

[26] LIU, X., SUN, J., YANG, Y., ZHOU, F., PU, Z., LI, L. and ZHENG, Y. (2016), Microstructure, mechanical properties, in vitro degradation behavior and hemocompatibility of novel $\mathrm{Zn}-\mathrm{Mg}-$ Sr alloys as biodegradable metals. In: Materials Letters, Vol. 162. pp. 242-245.

[27] POPA, C.L., BARTHA, C.M., ALBU, M., GUÉGAN, R., MOTELICA-HEINO, M.,
CHIFIRIUC, C.M., BLEOTU, C., BADEA, M.L. and ANTOHE, S. (2015), Synthesis, characterization and cytotoxicity evaluation on zinc doped hydroxyapatite in collagen matrix. In: Digest Journal of Nanomaterials and Biostructures, Vol. 10, No. 2, pp. 681-691.

[28] YANG, H., QU, X., LIN, W., WANG, C., ZHU, D., DAI, K. and ZHENG, Y. (2018), In vitro and in vivo studies on zinc-hydroxyapatite composites as novel biodegradable metal matrix composite for orthopedic applications. In: Acta Biomaterialia, Vol. 71. pp. 200-214.

[29] POOLOGASUNDARAMPILLAI, G. and NOMMEOTS-NOMM, A. (2017). 3 - Materials for 3D printing in medicine: Metals, polymers, ceramics, hydrogels. In: $3 D$ Printing in Medicine, pp. 43-71. Woodhead Publishing, United Kingdom.

[30] DING, W. (2016), Opportunities and challenges for the biodegradable magnesium alloys as nextgeneration biomaterials. In: Regenerative biomaterials, Vol. 3, No. 2, pp. 79-86.

[31] HERMAWAN, H., DUBÉ, D. and MANTOVANI, D. (2010), Developments in metallic biodegradable stents. In: Acta Biomaterialia, Vol. 6, No. 5, pp. 1693-1697.

[32] MORAVEJ, M., PRIMA, F., FISET, M. and MANTOVANI, D. (2010), Electroformed iron as new biomaterial for degradable stents: Development process and structure-properties relationship. In: Acta Biomaterialia, Vol. 6, No. 5, pp. 1726-1735.

[33] ČAPEK，J., PINC，J., MSALLAMOVÁ, ড̌., JABLONSKÁ, E., VEŘTÁT, P., KUBÁSEK, J. and VOJTĚCH, D. (2019), Thermal Plasma Spraying as a New Approach for Preparation of Zinc Biodegradable Scaffolds: A Complex Material Characterization. In: Journal of Thermal Spray Technology, Vol. 28, No. 4, pp. 826-841.

SAKAI, T., BELYAKOV, A., KAIBYSHEV, R., MIURA, H. and JONAS, J.J. (2014), Dynamic and post-dynamic recrystallization under hot, cold and severe plastic deformation conditions. In: Progress in Materials Science, Vol. 60. pp. 130207. 